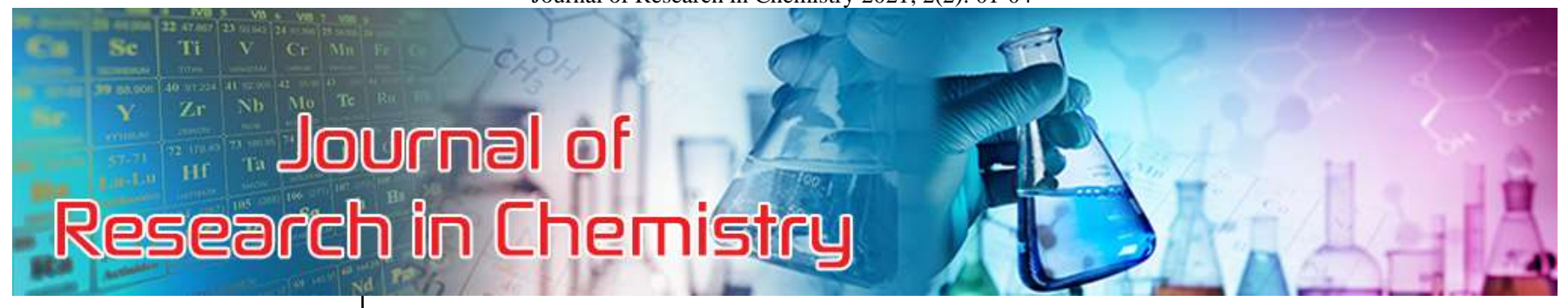

E-ISSN: 2709-9423

P-ISSN: 2709-9415

JRC 2021; 2(2): 01-04

(C) 2021 JRC

www.chemistryjournal.net

Received: 01-06-2021

Accepted: 04-07-2021

\section{Aqsa S}

Department of Chemistry, Faculty of Government College University Lahore, Pakistan

\section{Madiha B}

Department of Chemistry, Faculty of Lahore College for Women University Lahore, Pakistan

\section{Ayesha}

Department of Chemistry, Faculty of Govt Post Graduate Islamia College for Women Cooper Road Lahore, Pakistan

\section{Mohammad N}

Department of

Pharmaceuticals, Faculty of Applied Chemistry Research Center at Pakistan Council of Scientific and Industrial Research (PCSIR) Lahore, Pakistan

\section{Removal of oxytetracycline in pharmaceutical effluents by using synthetic adsorbents}

\author{
Aqsa S, Madiha B, Ayesha and Mohammad N
}

\begin{abstract}
Simple, accurate, fast, and economical method for removal of OTC in pharma wastewater has been developed. The procedure is based on the adsorption mechanism which leads to the spectrophotometry. Bentone -34 clay is used as an adsorbent for removal of OTC. $0.1 \mathrm{~N} \mathrm{HCl}$ was used as a mobile phase. The elute was determined spectroscopically, with a Cecil CE 2041 UV/VIS spectrophotometer, in a 1$\mathrm{cm}$ cuvette cell at wavelength range 190-1100 nm, with resolution $0.5 \mathrm{~nm}$. The linear calibration curve was established in the concentration range $0.214-1.070 \mathrm{mg} / \mathrm{mL}$ of OTC. From the analyzed data the following results for parameters were obtained linearity correlation $\mathrm{R}^{2}>0.9984$ ), accuracy (Recovery $=$ 91-98\%), sensitivity (LOD $=42.3 \mathrm{mg} / \mathrm{mL} ; \mathrm{LOQ}=48.3 \mathrm{mg} / \mathrm{mL}$ ), and precision $(\mathrm{RSD} \geq 2.0 \%)$ in the respective linear concentration ranges. The method is successfully applied for the removal of OTC as the tested sample improves ICH parameters like accuracy, sensitivity, precision.
\end{abstract}

Keywords: Economical method, Pharma wastewater, synthetic adsorbents

\section{Introduction}

Antibiotics have saved countless lives since their discovery, large quantities of these drugs are widely administered and used as antimicrobial drugs throughout the world ${ }^{[1]}$. Antibiotic drugs are predominantly used to treat bacterial diseases in human therapy and as veterinary medicines to prevent diseases in animal husbandry, and function as growth promoters, mainly in livestock ${ }^{[2]}$. Oxytetracycline (OTC), (a natural metabolic product of a bacterium, Streptomyces Rimosus.) [3] as one kind of typical tetracyclines, possess a wide range of antimicrobial activity against gram-positive and gram-negative bacteria ${ }^{[4]}$. Tetracyclines is widely used in the clinical treatment and livestock industry, and as growth promoter due to its broad spectrum of activity and low cost ${ }^{[5]}$. Tetracyclines contribute approximately $50 \%$ of total antibiotics production ${ }^{[6]}$. Due to its wide antibacterial spectrum, Oxytetracycline (OTC) is a common antibiotic used to treat different food-producing animals such as cattle, pigs, sheep and poultry, as well as in dogs and cats and fish. Usually it is administered orally with feed dosage rate of $25-700 \mathrm{mg} / \mathrm{kg}{ }^{[7,8]}$ Oxytetracycline is ionized throughout the $\mathrm{pH}$ range, existing in the cationic form below $\mathrm{pH} 3.3$, as a zwitterion between $\mathrm{pH} 3.3$ and 7.7, and an anion above $\mathrm{pH} 7.7^{[9]}$. Tetracyclines, generally act as bacteriostatic antibiotics, by inhibiting the protein synthesis by reverse binding the $30 \mathrm{~S}$ ribosomal subunits of susceptible organisms, and preventing access of aminoacyl-tRNA to the acceptor site on the mRNAribosome complex. Tetracyclines also are believed to reversibly bind to 50S ribosomes and additionally alter cytoplasmic membrane permeability in susceptible organisms. In high concentrations, tetracyclines can also inhibit protein synthesis by mammalian cells ${ }^{[10,11]}$. The widespread production and use of natural tetracyclines in both human and animal medicine in the decades following their discovery led to emergence of resistance mechanisms and decreased effectiveness as front-line antibiotics ${ }^{[12]}$. OTC affected algae and other bacteria by decreasing their population numbers, while it could cause death to invertebrates and fish ${ }^{[13]}$. In a natural aquatic system, the available concentration for bioaccumulation depends on how fast the compound is degraded and how much the compound is sorbet in the sediment. Therefore, the bioavailability of OTC for the aquatic organism will vary with the environmental conditions and the consumption behaviors of each aquatic species ${ }^{[14]}$. The bioaccumulations of OTC in farm animals such as chicken, swine and cow were higher than that found in aquatic species. This is probably because they uptake OTC directly from their feed while aquatic species obtained OTC from their environment ${ }^{[15]}$. The ingestion of OTC contaminated food could pose a potential risk to human health. Varieties of toxic and irritation effects in humans have been reported ranging from minor effects such as sore throat, nausea and diarrhea to serious illness such as peripheral blood and liver injury ${ }^{[16]}$.

\author{
Correspondence \\ Department of Chemistry, \\ Faculty of Government College \\ University Lahore, Pakistan
}


Degradation of OTC is one factor that reduces its concentration in soil, water and sediment, hence decreasing its bioavailability and toxicity to the organism ${ }^{[17]}$. Several methods reported in the literature for the determination of tetracyclines are expensive, time consuming and are not useful for the routine analysis ${ }^{[18]}$, but adsorption was an old scientific subject and adsorption -based technologies were industrially important that attracted people. As adsorption of tetracyclines, oxytetracycline in the present case, on isolated clays, organic clays, soils, organic matters and marine sediment has been previously investigated ${ }^{[19]}$. The present work involved a study of the adsorption process of the oxytetracycline (OTC) from aqueous solution by Bentone34 as adsorbent material. (Bentone 34 is an organic derivative of a special smectite. It is manufactured by chemically modifying naturally occurring clays like bentonite) $[20,21]$. Choosing Bentone -34 as adsorbent because of its non-toxicity, adsorption properties and low-cost material. The aim of my study was to develop a simple, accurate, fast, and economical method for removal of OTC in pharma wastewater with minimal materials.

\section{Materials and Methods}

\section{Apparatus and spectrophotometric conditions}

Cecil CE 2041 UV/VIS spectrophotometer 1-cm quartz cell at wavelength range $190-1100 \mathrm{~nm}$, with resolution $0.5 \mathrm{~nm}$ and scan rate of $1-4000 \mathrm{~nm} / \mathrm{min}$.

Required chemicals:

\section{Standard stock solution of oxytetracycline}

A $1000 \mathrm{ppm}$ standard stock solution of oxytetracycline (OTC) was prepared by mixing $50 \mathrm{ml}$ of Oxytetracycline containing waste water in $50 \mathrm{~mL}$ of $0.1 \mathrm{~N} \mathrm{HCl}$ (standard soln.) in the $50 \mathrm{~mL}$ beaker.

$50 \mathrm{ml}(\mathrm{OTC}) 50 \mathrm{~mL}(0.1 \mathrm{~N} \mathrm{HCl})=50 \mathrm{ml} / 50 \mathrm{~mL}=1 \mathrm{ml} / \mathrm{mL}$

$\frac{1 \times 1000}{\mathrm{ml} \times 1000}=1000 \mathrm{ppm}$

\section{Standard 0.1N HCl solution}

Add $4.5 \mathrm{ml}$ of $\mathrm{HCl}$ in the $500 \mathrm{ml}$ conical flask and fill it to $500 \mathrm{ml}$ mark with distilled water to create a $0.1 \mathrm{~N} \mathrm{HCl}$ solution.

\section{Preparation of 40ppm sample solution}

A 40ppm sample solution of OTC was prepared by pipette out $2 \mathrm{ml}$ of stock solution in a $50 \mathrm{ml}$ beaker and then fill it to a $50 \mathrm{ml}$ of $0.1 \mathrm{~N} \mathrm{HCl}$ standard solution.

$2 \mathrm{ml}($ stock) $50 \mathrm{~mL}(0.1 \mathrm{~N} \mathrm{HCl})=2 \mathrm{ml} / 50 \mathrm{ml}$

$\frac{2 \times 20}{50 \times 20}=\frac{40 \times 1000}{1000 \times \mathrm{ml}}=40 \mathrm{ppm}$

Preparation of different sample solutions Different working sample concentrations were prepared identically as previously mentioned by pipetting out $4 \mathrm{ml}$, $6 \mathrm{ml}, 8 \mathrm{ml}, 10 \mathrm{ml}$ respectively aliquots of stock solution into a separate beaker of $50 \mathrm{ml}$.

\section{Preparation of $80 \mathrm{ppm}$ sample solution}

$4 \mathrm{ml}($ stock) $50 \mathrm{~mL}(0.1 \mathrm{~N} \mathrm{HCl})=4 \mathrm{ml} / 50 \mathrm{ml}$

$\frac{4 \times 20}{50 \times 20}=\frac{80 \times 1000}{1000 \times \mathrm{ml}}=80 \mathrm{ppm}$
Preparation of 120ppm sample solution

$6 \mathrm{ml}$ (stock) $50 \mathrm{~mL}(0.1 \mathrm{~N} \mathrm{HCl})=6 \mathrm{ml} / 50 \mathrm{ml}$

$\frac{6 \times 20}{50 \times 20}=\frac{120 \times 1000}{1000 \times \mathrm{ml}}=120 \mathrm{ppm}$

Preparation of $160 \mathrm{ppm}$ sample solution

$8 \mathrm{ml}($ stock) $50 \mathrm{~mL}(0.1 \mathrm{~N} \mathrm{HCl})=8 \mathrm{ml} / 50 \mathrm{ml}$

$\frac{8 \times 20}{50 \times 20}=\frac{160 \times 1000}{1000 \times \mathrm{ml}}=160 \mathrm{ppm}$

Preparation of 200ppm sample solution

$10 \mathrm{ml}($ stock) $50 \mathrm{~mL}(0.1 \mathrm{~N} \mathrm{HCl})=10 \mathrm{ml} / 50 \mathrm{ml}$

$\frac{10 \times 20}{50 \times 20}=\frac{200 \times 1000}{1000 \times \mathrm{ml}}=200 \mathrm{ppm}$

\section{Procedure}

\section{Running of standard $0.1 \mathrm{~N}$ HCl through column}

The first step to check out any impurity in the benton-34 clay, $10 \mathrm{ml}$ standard $0.1 \mathrm{~N} \mathrm{HCl}$ solution was run through the column. Collect $5 \mathrm{ml}-7 \mathrm{ml}$ of eluted sample in a separate beaker. To analyze any impurity in the clay, UV-VIS spectrophotometry has been done to the eluted sample.

\section{Running of sample solution}

In the next step $25 \mathrm{ml}$ of $40 \mathrm{ppm}$ sample solution of OTC (previously prepared) was run through the column. Collect $10 \mathrm{ml}-15 \mathrm{ml}$ of eluted sample in a separate beaker. To analyze the quantity of OTC removed, UV-VIS spectrophotometry has been done to the eluted sample.

\section{Data analysis}

For determination of the statistical parameters, the Microsoft Office Excel is used.

\section{Result and Discussion \\ ICH QC method Validation}

All of the analytical validation parameters for this proposed method were determined according to the $\mathrm{ICH}$ guidelines [22].

\section{Linearity range}

The Linearity of the proposed spectroscopic method was determined at 5 concentration levels ranging from 0.214 $1.07 \mathrm{mg} / \mathrm{ml}$, and calibration curve was constructed by plotting the respective concentrations at detector's response i.e. absorption maxima $(254 \mathrm{~nm})$. Linear correlation in the above mentioned concentration range was confirmed and linear regression equation was $y=0.1745 x+0.0026$ with the coefficient of correlation of $\mathrm{R} 2=0.9984$.

\section{Precision}

The precision of the proposed method was estimated by calculating the relative standard deviation as the average of 5 measurements. The $\%$ RSD value is 3 found to be 2.73 for OTC in terms of analytical recovery calculations.

\section{Accuracy}

The accuracy of the proposed methods was determined in terms of recovery as the average of 5 measurements. The recoveries calculated $(91 \%$ to $98 \%)$ indicate that the proposed methods are accurate. 


\section{Sensitivity}

Both the Limit of Detection (LOD) determination at lowest concentration giving response and Limit of Quantification (LOQ) determination were estimated from the standard deviation of the response and the slope, based on the data of the calibration curve. The limit of detection (LOD) and limit of quantification (LOQ) were found to be $42.3 \mathrm{mg} / \mathrm{mL}$ and $48.3 \mathrm{mg} / \mathrm{ml}$. The LOD and LOQ showed that this method is sensitive for OTC determination.

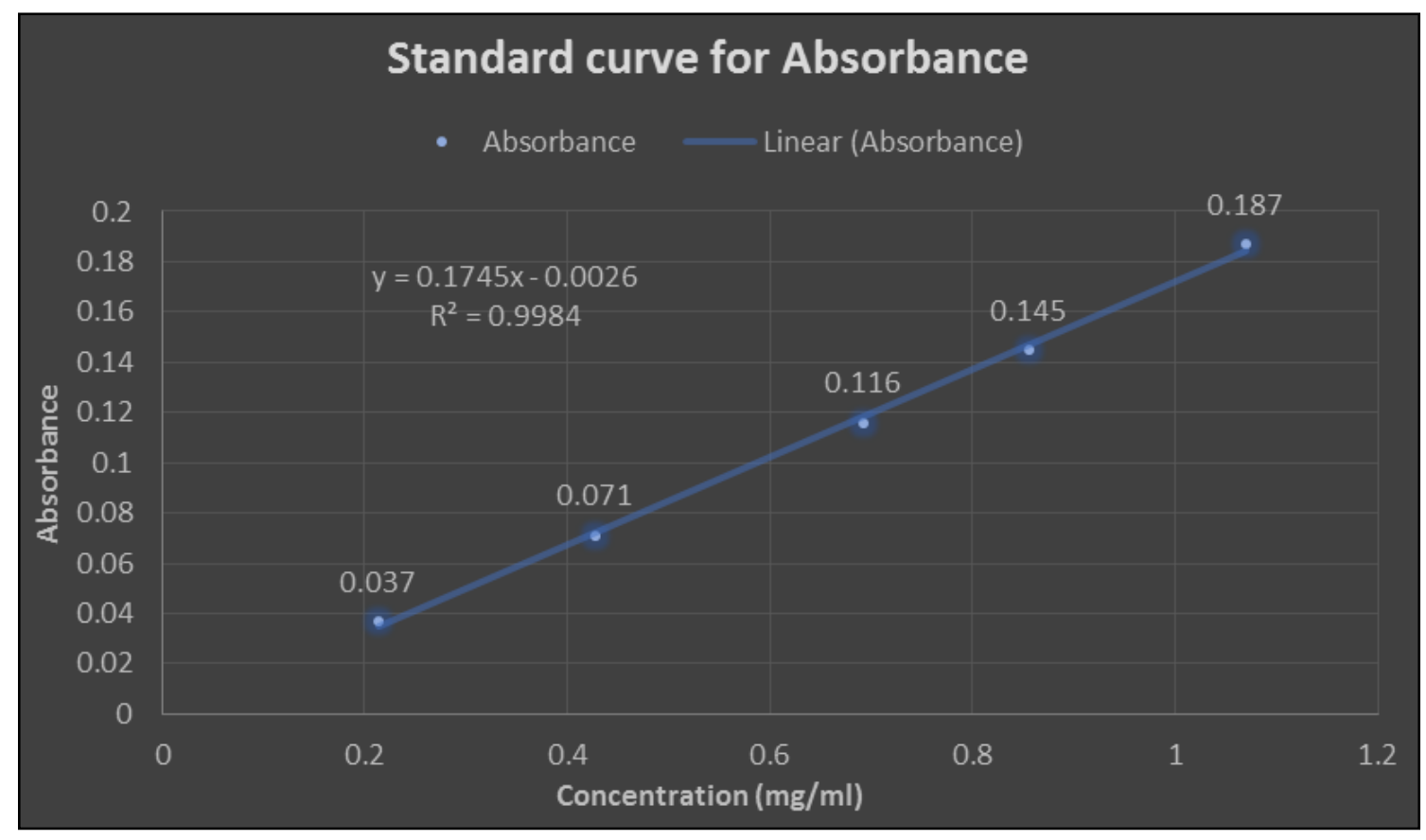

Fig 1: Standard Absorption Curve of OTC at $\lambda \max =254 \mathrm{~nm}$

Table 1a: Validation summary for determination of the statistical parameters, the Microsoft Office Excel.

\begin{tabular}{|c|c|c|c|c|}
\hline Test no. & Concentration (mg/ml) & Absorbance & Found Concentration (mg/ml) & Recovery (\%) \\
\hline 1 & 0.214 & 0.037 & 0.19713467 & 92.1190049 \\
\hline 2 & 0.428 & 0.071 & 0.391977077 & 91.58342929 \\
\hline 3 & 0.692 & 0.116 & 0.649856734 & 93.90993259 \\
\hline 4 & 0.856 & 0.145 & 0.816045845 & 95.33245856 \\
\hline 5 & 1.07 & 0.187 & 1.056733524 & 98.76014246 \\
\hline Mean & & & & 94.34099356 \\
\hline SD & & & & 2.578336197 \\
\hline SE of intercept & & & & 0.002895499 \\
\hline SD of intercept & & & & 2.238963476 \\
\hline LOD & & & & 42.34142964 \\
\hline LOQ & & & & 48.3073625 \\
\hline
\end{tabular}

Table 1b: Validation summary for all of the analytical validation parameters for this proposed method were determined according to the ICH guidelines standard/test solution.

\begin{tabular}{|c|c|c|}
\hline Analytical technique & & UV/VIS Spectrophotometry \\
\hline Type apparatus for Validation & & Cecil CE-2041 UV/VIS Spectrophotometer \\
\hline Validation parameters & Acceptance Criteria & Results \\
\hline Range & min. acceptable 20-100\% & $0.214-1.07 \mathrm{mg} / \mathrm{ml}$ of OTC \\
\hline $\begin{array}{c}\text { Linearity } \\
\text { Correlation coefficient } \mathrm{R}^{2}\end{array}$ & $\geq 0.9900$ & 0.9984 \\
\hline $\begin{array}{c}\text { Sensitivity: } \\
\text { LOD }\end{array}$ & & $42.3 \mathrm{mg} / \mathrm{ml}$ \\
\hline LOQ & $91-98 \%$ & $48.3 \mathrm{mg} / \mathrm{ml}$ \\
\hline $\begin{array}{c}\text { Accuracy: } \\
\text { Recovery: }\end{array}$ & RSD $\%$ & Recovery $=94.3 \%$ \\
\hline $\begin{array}{c}\text { Precision: } \\
\text { (method repeatability) }\end{array}$ & $\begin{array}{c}\mathrm{s}=2.23 \\
\geq 2.73 \%\end{array}$ \\
\hline
\end{tabular}

\section{Conclusion}

In the present novel study the adsorption of the Oxytetracycline (OTC) from pharma wastewater on bentone-34 clay was investigated. The international council of Harmonization ( $\mathrm{ICH})$ guidelines was used for all the analytical validation parameters for this proposed method.
For the determination of data analysis Microsoft Excel was used. Beer - Lambert's law is obeyed in the range 0.214 $1.070 \mathrm{mg} / \mathrm{ml}$. The linear calibration curve was established in the 5 concentration level ranges $(0.214-1.070 \mathrm{mg} / \mathrm{mL})$ of OTC. As from the analyzed data the following results for parameters were obtained, as linear regression equation was 
$\mathrm{y}=0.1745 \mathrm{x}+0.0026$ with linearity correlation $\left.\mathrm{R}^{2}>0.9984\right)$, accuracy (Recovery $=91-98 \%$ ), sensitivity (LOD $=42.3$ $\mathrm{mg} / \mathrm{mL} ; \mathrm{LOQ}=48.3 \mathrm{mg} / \mathrm{mL}$ ), and precision $(\mathrm{RSD} \geq 2.0 \%$ ) in the respective linear concentration ranges. The method is successfully applied for the removal of OTC as the tested sample improves ICH parameters like accuracy, precision, sensitivity. The results of the present study are indicative of Bentone-34 as a new alternative low-cost adsorbent for removing the oxytetracycline from pharma wastewater.

\section{References}

1. Kebede TG, Dube S, Nindi MM. Removal of multiclass antibiotic drugs from Wastewater using watersoluble protein of Moringa stenopetala seeds. Water 2019;11:1.

2. Jaruwan $\mathrm{H}$, Boonsaner $\mathrm{M}$. Bioaccumulation of Oxytetracycline in Aquatic Organisms and Farm Animals and Its Risk on Human Health. Journal of Health Research 2016;30(1):53-58.

3. Prasad ARG, Rao VS. Spectrophotometric methods for the microdetermination of oxytetracycline and hostacycline. Science World Journal 2010;5(1).

4. Nan W, Pan P, Zeng M, Wang W, Xu C, Zhang Z, et al. Oxytetracycline removal from water by novel microbial embedding gel beads. In IOP Conference Series: Earth and Environmental Science, vol. 108, no. 4, p. 042004. IOP Publishing 2018.

5. Bansal OP. Sorption of Tetracycline, Oxytetracycline, and Chlortetracycline in Illite and Kaolinite Suspensions. ISRN Environmental Chemistry 2013, 18.

6. Naumoska M, Dimitrieska-Stojković E, Stojković G. Comparison of spectrophotometric and complex metricspectrophotometric assay for determination of oxytetracycline in veterinary drugs." In Book of Proceedings, Days of Veterinary Medicine 2012, 3rd International Scientific Meeting, Macedonia, 2-4 September 2012, University" Ss Cyril and Methodius" in Skopje, Faculty of Veterinary Medicine in Skopje 2012, 165-169.

7. Schmidt LJ, Gaikowski MP, Gingerich WH, Dawson VK, Schreier TM. An environmental assessment of the proposed use of oxytetracycline-medicated feed in freshwater aquaculture. US Geological Survey, Biological Resources Division 2007.

8. Pickens LB, Tang Y. Oxytetracycline biosynthesis. Journal of Biological Chemistry 2010;285(36):2750927515.

9. Harja M, Ciobanu G. Removal of oxytetracycline from aqueous solutions by hydroxyapatite as a low-cost adsorbent. In E3S Web of Conferences 2017;22:1.

10. Elementis S, Bentone. -34 Elementis Specialties 2018, 01.

11. ICH guidelines. European Medicines Agency CPMP/ICH/381/95 1995-2020. 